\title{
RECREATION OR DECORATION: WHAT WERE THE GLASS COUNTERS FROM POMPEII USED FOR?
}

\author{
by H.E.M. Cool
}

\begin{abstract}
This paper considers the small glass objects often called counters, which are common finds at Pompeii, and normally thought to have been used in playing games. An assemblage of over 500 stratigraphically dated examples from Insula VI.1 are examined, and the colour and size of this group are compared to a dataset of first-century $A D$ glass counters found in graves where they can be shown with certainty to be part of gaming sets. The comparisons show that the bulk of the Pompeii counters are very unlikely to have been used in gaming, a conclusion that is supported by the types of counters that would have been necessary to play games such as ludus latrunculorum and ludus duodecim scriptorum. Other functions are considered and it is suggested that many of the Pompeiian counters might have been used for interior decoration. The rise of a specialist production of counters that could have been used in gaming is demonstrated, and it is suggested this might have implications for the development of craft specialization and demonstrate the rise of leisure time in the first century $A D$.
\end{abstract}

Questo articolo esamina i piccoli oggetti di vetro spesso chiamati 'pedine', ritrovamenti comuni a Pompei e che generalmente si pensa che fossero usati in relazione all'attività ludica. Viene esaminato un insieme di più di 500 esemplari dalla Insula VI.1, datati su base stratigrafica, e il colore e la dimensione di questo gruppo vengono paragonati a quelli di un insieme di 'pedine' vitree risalenti al I sec. $d$.C., rinvenuti in tombe e di cui è certo l'utilizzo come parti di set da gioco. Il paragone mostra come la maggior parte delle 'pedine' da Pompei difficilmente sia stata utilizzata in relazione ad attività ludiche. Questa conclusione è supportata da un'analisi che tiene conto dei tipi di pedine che sarebbero stati necessari per giochi come il ludus latrunculorum $e$ il ludus duodecim scriptorum. Si prendono quindi in considerazione altre possibili funzioni e si suggerisce come molte delle 'pedine' da Pompei fossero utilizzate per decorazioni d'interni. Nell'articolo viene inoltre evidenziato lo sviluppo di una produzione specialistica di 'pedine' utilizzabili nelle attività ludiche e si suggerisce come ciò abbia potuto avere implicazioni nello sviluppo della specializzazione delle tecniche artigianali e dimostra l'aumento della disponibilità di 'tempo libero' nel I sec. d.C.

\section{INTRODUCTION}

A regular find at Pompeii is a small glass disc with an approximately circular outline and a plano-convex section. Allison $(2004)^{1}$ recorded over 70 from 6 of the 30 eruption level house assemblages she studied, whilst Cerato (1998:

1 Search conducted on the database accompanying this volume using the search-terms material $=$ 'glass' and artefact $=$ 'bottone'. See www.stoa.org/pompeianhouseholds. 
fig. 21) shows several hundred from House I.11.9. Depending on the nationality of the excavating team finding them, these will normally be called counters, pedine, pions or Spielsteine because this is what archaeologists traditionally call such objects. ${ }^{2}$ All these terms are suggestive of playing-pieces used in games. Assigning function to the objects in this way is not surprising, especially at Pompeii. It is, for example, unusual in any exhibition or popular book that seeks to depict daily life in Pompeii for there not to be a reproduction of the wall painting from the Caupona of Salvius (Pompeii VI.14.36). This shows two drinkers seated at a table where counters are laid out, arguing over the value of the dice throw that has just been made. ${ }^{3}$ Elsewhere counters and dice are found together in graves, and are very occasionally even found laid out on a board in a grave as though awaiting a game to be played in the afterlife (Crummy et al., 2007: 52-9). In this paper a large group of over 500 of these counters from a single insula at Pompeii will be examined and it will be argued that when they are considered in detail, the simple equation that a counter is always a playingpiece cannot be sustained. Instead it seems very likely that an important element of interior decoration is being overlooked. Exploring them in detail also provides insights into the specializations in craft and industry that were emerging in the first century $\mathrm{AD}$ as a growing consumerism developed (Green, 2008: 74). Differentiating between those probably used for gaming and those used for other purposes also allows the possible growth of leisure time to be considered. It will be shown that there is a noticeable increase in the types and numbers of those most probably used for gaming from the mid-first century AD. The obvious conclusion to draw from this is that the demand increased because more people were spending their time in this pursuit.

There are a limited number of attributes that can be used to analyse glass counters. As they are all fundamentally the same shape, morphology is of little help. The plano-convex form is the direct result of the working properties of glass. If a soda lime silicate glass is heated to a temperature of $c .625^{\circ} \mathrm{C}$ (Stern and Schlick-Nolte, 1994: 22), the sharp edges on any chunk of glass will start to soften and become round. The counters have smooth rounded upper surfaces and flat lower surfaces that can be pitted, precisely what might be expected if suitably sized chunks of broken vessels were heated on a flat surface.

One obvious analytical variable is the type of glass used to make them. At a basic level it can be divided into translucent and opaque. 'Black' counters are a special case as they are normally made with translucent glass which is so dark that no light can be seen through it other than in very thin edges of breaks. The opaque and translucent counters can be further divided according to whether they are made of two or more colours (bi- and polychrome), or whether they

2 For English usage see Crummy, 1984: 92; for Italian, Varone, 2003: 193; for French, Foy, 2010: 458; and for German, Rütti, 1988: 100.

3 For exhibitions see for example Ward-Perkins and Claridge, 1979: no. 227; d'Ambrosio et al., 2003: 273-4; Roberts, 2013: 63 fig. 58. For popular books see for example Berry, 2007: 232 and Beard, 2008: plate 13. 
are monochrome. The monochrome ones can then be subdivided according to the different colours and shades. Size can also be measured and is an important attribute. When considered at any length, the range noted also raises questions about whether all plano-convex glass discs had the same function as is often casually assumed.

\section{INSULA VI.1 POMPEII AND ITS DATING}

The counters considered here come from the excavations in Insula VI.1 conducted by the Anglo-American Project in Pompeii between 1995 and 2006. ${ }^{4}$ The insula is triangular in shape and lies adjacent to the Porta Ercolano. It is bounded by the line of the city walls to the northwest, the main thoroughfare of the Via Consolare to the west and the small Vicolo Narciso to the east (see Fig. 1). At the time of the eruption it was home to two elite houses, the Casa delle Vestali and the Casa del Chirurgo. There was a property immediately by the Porta Ercolano identified as an Inn, and this had an outdoor dining room known as the Triclinium. In the southern part of the insula there was a shrine, an industrial workshop area and two bars known conventionally as the bars of Acisculus and Phoebus. Two additional bars were located on the Via Consolare frontages of the Inn and the Casa delle Vestali. Parts of the Via Consolare frontage and all of the Casa del Chirurgo had originally been uncovered to the eruption level by the Bourbon excavators in 1770 and 1771, and the excavation of the rest of the insula was completed between 1783 and 1789 (Fiorelli, 1860: Part 1, 236-57, Part 2, 18-46).

When working with material from excavations at Pompeii we are blessed with one undoubted historically fixed point, the eruption of $\mathrm{AD} 79$, which provides the terminus ante quem. Another historically attested episode is the earthquake that Tacitus and Seneca describe as damaging Pompeii in AD 62 or 63. Modern scholarship points to the possibility that the earthquake may not have been a single event and that seismic activity necessitating repair and rebuilding may have taken place over a number of years in the Neronian and early Flavian periods. 5 Here AD 62 will be used as a terminus post quem indicating earthquake-related episodes that resulted in demolition and rebuilding in the stratigraphic sequence, acknowledging that not all may have been precisely contemporaneous. The position of the insula also provides a third fixed historical point. In 89 BC the Roman army of Lucius Cornelius Sulla besieged

\footnotetext{
4 Articles published about the excavations while they were ongoing include Jones and Robinson, $2004 ; 2005 a ; 2005 b ; 2007$. There are final publications of the coins and the botanical evidence, and both of those works include summaries of the stratigraphic narrative: see Hobbs, 2013: 68-75 and Murphy, 2015: 15-24. The full dataset for the counters and information about other categories of finds from the insula mentioned in this paper will appear in Cool, forthcoming.

5 For a discussion of the ancient sources and an overview of this debate see Allison, 2004: 14-19; see also Keenan-Jones, 2015: 191 n. 1.
} 


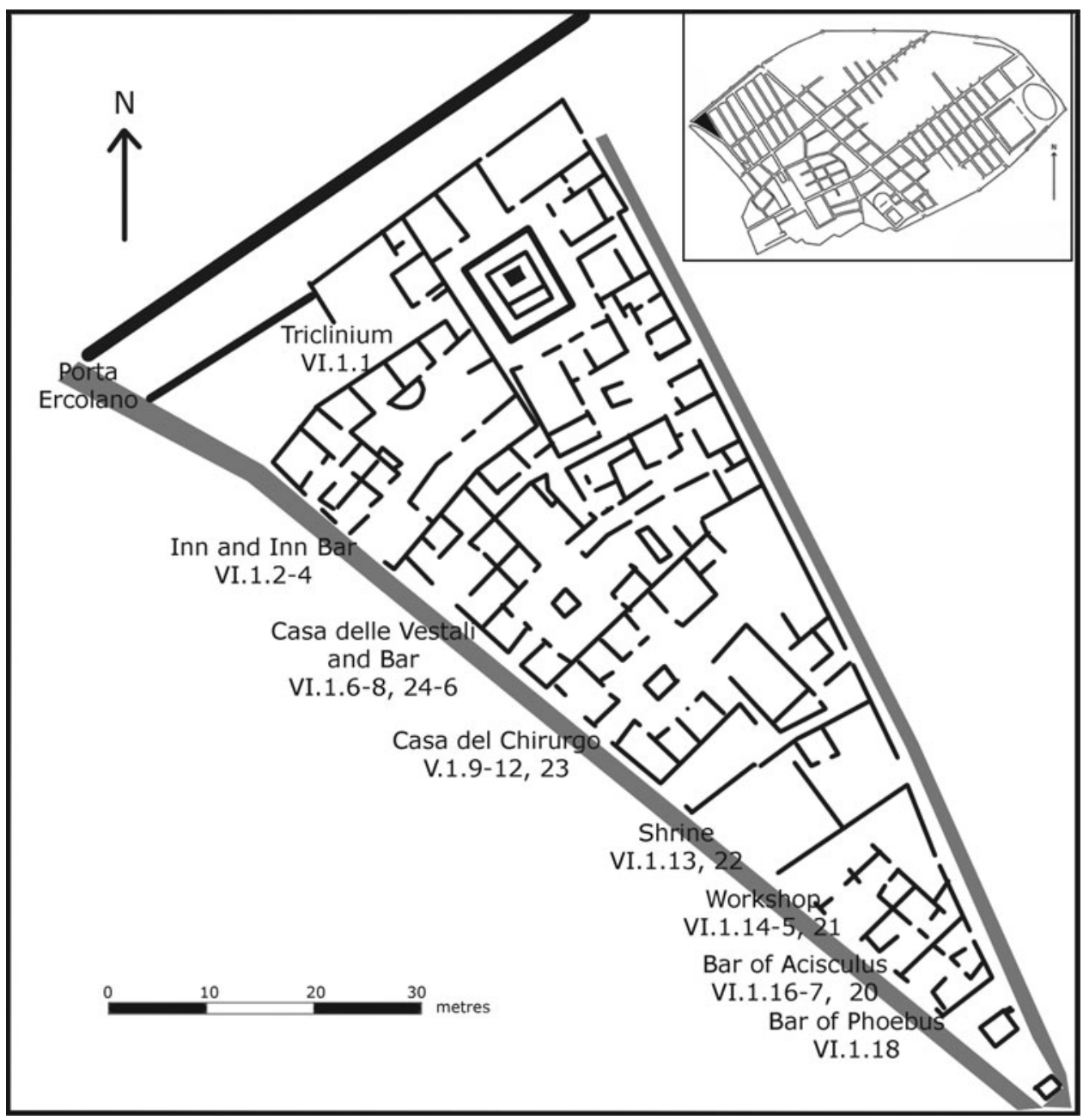

Fig. 1. The properties in Insula VI.1. The inset shows the location of the insula within Pompeii.

Pompeii. On the outer face of the city wall that borders the insula, impact craters from siege missiles can be seen. ${ }^{6}$ Within the stratified sequence of VI.1 the numerous lead slingshots recovered provide another secure terminus post quem for the many destruction deposits.

The aim of the recent work was to excavate all of the pre-eruption level archaeology unless the presence of solid floors or safety considerations prevented it. In principle this takes the stratified finds back into the fourth century BC (Jones and Robinson, 2004: 109). In reality it is not until the second century $\mathrm{BC}$ that artefacts other than pottery start to occur in any quantity. The

6 This is another illustration that regularly occurs in popular works dealing with Pompeii. See for example Berry, 2007: 84; Roberts, 2013: 24 fig. 10 (incorrectly dated). 
main focus of deposition starts in the late first century BC, when the various properties underwent considerable changes in use. Up to that point, the area where the Inn was to be had lain derelict after the destruction caused by the Sullan siege, and much of the Via Consolare frontage not occupied by the houses had been given over to industrial activities requiring large tanks. These areas and the large houses underwent frequent alterations from the late first century BC onwards resulting in sequences of levelling layers and new floors in which considerable amounts of finds were incorporated.

As a result of the redevelopments, there is a large and well-stratified sequence of material that allows changing patterns of use to be documented and this helps disentangle the problem of what the counters were used for. The various properties had their own chronologies of change and these were not contemporaneous. In the study of the material culture it has been found useful to define broad overlapping date bands. While subject to the same uncertainty of precise dates that any archaeological sequence shows, the chronological markers of the Sullan siege, the earthquake and the eruption do provide the VI.1 sequence with a fairly reliable framework. The broad date bands used for this paper are as follows:

1. Third to second century BC: this includes the material from contexts that clearly relate to occupation prior to the Sullan siege of 89 BC. Some caution has to be exercised over some of the contexts currently phased to this period as they might be later.

2. First century BC: this extends from the Sullan siege destruction and overlaps in its terminal date with the early years of the next period.

3. Augusto-Tiberian: effectively this runs up to the early years of Tiberius (AD 20s). Much of the material was probably deposited within the last decade of the first century $\mathrm{BC}$ and the first decade of the following century.

4. Tiberian-Neronian: this runs up to the earthquake activity. Here, as discussed, conventionally placed in $c$. AD 62.

5. Augusto-Neronian: this covers the contexts where the relatively fine division between the two previous ones cannot be made.

6. Post $\mathrm{AD}$ 62: this includes the contexts associated with the rebuilding necessitated by earthquake damage and occupation deposits running up to the eruption.

7. Modern: this can be taken as a proxy for the eruption level of $\mathrm{AD} 79$. While the original Bourbon excavators may not have been quite so single-minded in searching for statues, wall paintings and other valuable items to grace the royal collections as has sometimes been asserted (see Parslow, 1995: 2-3), it is clear that less decorative items were discarded or overlooked on site. This is the only explanation that accounts for items such as complete or nearcomplete glass unguent bottles having been found in levels with modern material in the insula. 
With this chronological framework in place it is possible to start examining the counters themselves.

\section{THE GLASS COUNTERS: COLOUR}

In total 566 glass counters were recovered, making them the commonest small find from the excavation other than coins, of which there were 1,512 (Hobbs, 2013: 181). The counters were found in a considerable number of colours. Table 1 rationalizes the colours into twenty categories, but it should be stressed that the original recording noted a much bigger range of shades. Multi-coloured counters formed $6 \%$ of the assemblage with the remainder being monochrome. The monochrome counters may be divided between opaque glass (just under $6 \%$ of the total), 'black' glass (just under $10 \%$ ) and translucent glass, which

Table 1. The colours of the Insula VI.1 glass counters by broad phase category. The abbreviations in brackets after the row headings are used in Fig. 2. Those without abbreviations were excluded from the analysis on the grounds of the small numbers found in those colours.

\begin{tabular}{|c|c|c|c|c|c|c|c|c|c|}
\hline Colour & $\begin{array}{c}3 / 2 \\
B C\end{array}$ & $\begin{array}{c}1 \\
B C\end{array}$ & $\begin{array}{l}\text { Aug.- } \\
\text { Tib. }\end{array}$ & $\begin{array}{l}\text { Aug.- } \\
\text { Ner. }\end{array}$ & $\begin{array}{l}\text { Tib.- } \\
\text { Ner. }\end{array}$ & $\begin{array}{c}\text { Post } \\
62\end{array}$ & *Mod & $\begin{array}{l}* U n- \\
p h .\end{array}$ & Total \\
\hline $\begin{array}{l}\text { Multi-coloured } \\
\text { (Multi) }\end{array}$ & 2 & 1 & 6 & 3 & 8 & 5 & 5 & 5 & 35 \\
\hline Opaque white $(\mathrm{OpW})$ & - & 1 & 1 & 2 & 2 & 3 & 3 & 1 & 13 \\
\hline Opaque blue & - & - & 2 & 1 & 2 & 1 & 1 & - & 7 \\
\hline Opaque green & - & - & 1 & 1 & 3 & - & - & - & 5 \\
\hline Opaque blue/green & - & - & - & 1 & - & 3 & 1 & - & 5 \\
\hline Opaque yellow & - & - & - & - & - & 1 & - & - & 1 \\
\hline Black (Bl) & 3 & 1 & 7 & 3 & 12 & 10 & 8 & 11 & 55 \\
\hline $\begin{array}{l}\text { Dark yellow/brown } \\
\text { (DY/B) }\end{array}$ & $* * 3$ & - & 5 & 1 & 4 & 5 & 1 & 2 & 21 \\
\hline Purple & - & - & - & - & 1 & - & - & - & 1 \\
\hline Deep blue (DpB) & $* * 1$ & 1 & 14 & 3 & 8 & 11 & 5 & 3 & 46 \\
\hline Peacock & 1 & 1 & 4 & 2 & 4 & 3 & 3 & - & 18 \\
\hline Emerald green & - & 1 & - & 1 & 1 & 3 & 2 & - & 8 \\
\hline Mid/dark green & - & - & - & - & - & 2 & - & - & 2 \\
\hline Mid/light blue (MiB) & - & - & 4 & 1 & - & 4 & 1 & - & 10 \\
\hline Yellow/brown (Y/B) & $* 66$ & 4 & 17 & 5 & 13 & 15 & 7 & 9 & 76 \\
\hline Yellow/green (Y/G) & - & 4 & 8 & - & 5 & 3 & 6 & 2 & 28 \\
\hline Pale green $(\mathrm{PaG})$ & - & 2 & 10 & 5 & 8 & 12 & 7 & 10 & 54 \\
\hline $\begin{array}{l}\text { Green-tinged } \\
\text { colourless }(\mathrm{GtC})\end{array}$ & - & - & 5 & 3 & 2 & 2 & 2 & 2 & 16 \\
\hline Colourless (Cls) & $* 5$ & 2 & 17 & 3 & 11 & 6 & 5 & 3 & 52 \\
\hline Blue/green (B/G) & $* * 1$ & 4 & 14 & 14 & 10 & 31 & 25 & 8 & 107 \\
\hline Uncertain & - & - & 2 & 1 & 1 & - & 1 & 1 & 6 \\
\hline Total & 22 & 22 & 117 & 50 & 95 & 120 & 83 & 57 & 566 \\
\hline
\end{tabular}

* Mod = modern, Unph. = unphased.

** There are some doubts about the security of the phasing assigned to the third- to second-century $\mathrm{BC}$ contexts of three colourless, two yellow/brown and one each of the blue/green, deep blue and deep/yellow brown counters. 
accounted for the remaining part of the assemblage, approximately three-quarters of the total.

The commonest colour among the monochrome translucent glass counters was blue/green $(19 \%)$, followed by yellow/brown, with the very dark shades accounting for $4 \%$ and the lighter shades often variously described as amber or honey-coloured for $13 \%$. Other common colours, each accounting for $8-10 \%$ of the assemblage, were deep blue, pale green and colourless. As can be seen from the table, they occur throughout the stratified sequence and the steep upturn in numbers in the Augusto-Tiberian phase reflects the large numbers of levelling and other building layers that start to appear at that time. The incidence of examples that might be incorrectly phased to the third to second century BC is noted below the table.

An inspection of Table 1 shows that there are chronological changes. While some colours are proportionately well represented in the Augusto-Tiberian contexts (for example deep blue, yellow/brown), others such as blue/green and black have the bulk of their distribution later. To understand the data fully it is useful to inspect it via a Correspondence Analysis plot. The technique reduces a table of counts to a map where row profiles (the counts expressed as percentages) are represented by points; it is hoped that the closer the points are on the map the more similar their profiles are. Column profiles are similarly treated and both maps are inspected to see how row and column categories are related. ${ }^{7}$ Here the rows represent time and the columns colour. Where row and column profile points plot close together it indicates that at that time counters of that colour are proportionately better represented.

For the purpose of the analysis a simplified version of Table 1 was used where colours with less than ten counters were omitted. Due to the doubts over the integrity of the phasing for approximately a third of the counters assigned to the third to second century $\mathrm{BC}$, these were also omitted. To aid comprehension the overlapping Augusto-Neronian and Tiberian-Neronian periods were combined. The results of analysing this revised dataset of 452 counters are presented in Fig. 2. From the first century BC, the phasing appears in the classic horseshoe shape indicating a seriated sequence that can be associated with time. Yellow/green counters are typical of the first-century BC assemblage. The colourless and green-tinged colourless ones become more prominent in the following Augusto-Tiberian period. The Augusto-Neronian period is characterized by strongly coloured translucent and multi-coloured counters. Black was clearly becoming more important as time progressed, being typical of the post-earthquake period, while blue/green and opaque white characterize the modern deposits that can be taken as a proxy for the eruption level. The inertias of the first two axes sum to over $78 \%$, which is satisfactory, and indicate that the plot is a good representation of the data. The reasons for

\footnotetext{
This is a technique that was not much used up to c. 2000 in Roman archaeology though the situation has now changed. See Cool and Baxter, 1999; Pitts and Perring, 2006; Lockyear, 2013; and Pitts, 2014, with applications and further information.
} 


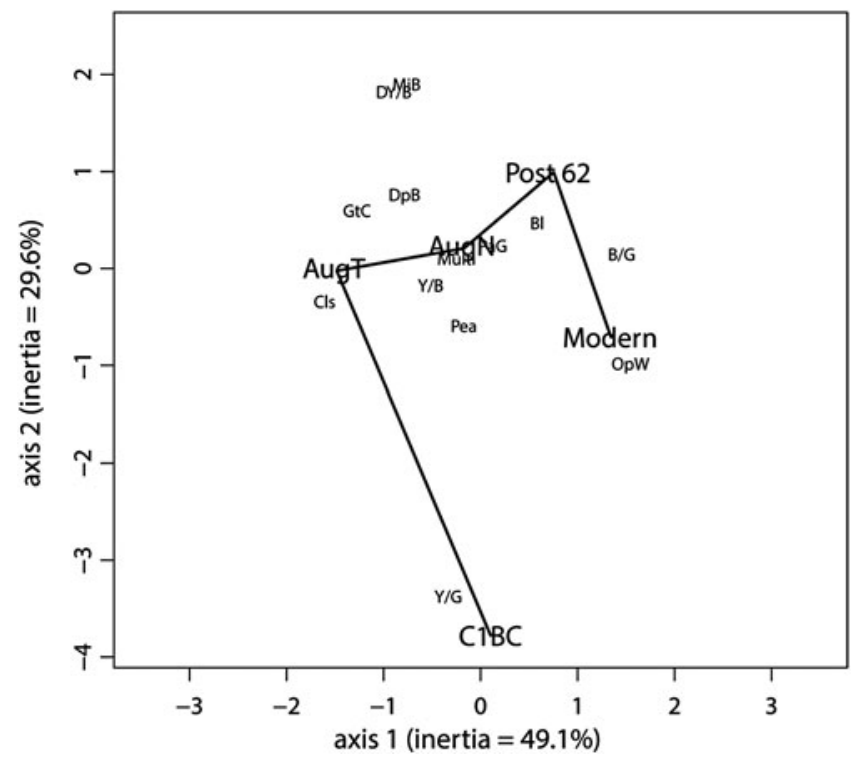

Fig. 2. A Correspondence Analysis showing the relationships of the colours of the VI. 1 counters to time. The abbreviations used for the colours are given in Table 1 (see text for additional explanation).

the chronological shift will be discussed later in the paper. At this point it is sufficient to note that it exists.

\section{THE GLASS COUNTERS: SIZE}

A little fewer than 500 of the counters are complete and have diameters that range from $5 \mathrm{~mm}$ to $26 \mathrm{~mm}$ with one outlier at $36 \mathrm{~mm} .{ }^{8}$ The interquartile range is 10 $14 \mathrm{~mm}$, the modal value is $11 \mathrm{~mm}$ and the median is $12 \mathrm{~mm}$. In comparison with glass counters that are believed to have been associated with playing games because they have been found as sets with dice in graves, the VI.1 counters are overwhelmingly small.

It is, of course, always open to question whether the sets of counters in graves were indeed used for gaming. The fact that they are found with dice, which, as will be discussed below, are a known necessity for one of the most popular games, and the fact that one set has been found laid out on a board as if for a game, strongly suggest that it is reasonable to conclude that the grave sets were indeed playingpieces. The grave dataset used consists of 156 counters in total from seven firstcentury AD graves. Two are from Taranto, one dating to the middle part and one to the middle and later part of the century (Schojer, 1988: 496 no. 37e, 498 no. 37.16j). One set is from a grave at San Vittore di Cingoli (Masarata,

8 Where the outline is oval the largest measurement has been taken. 


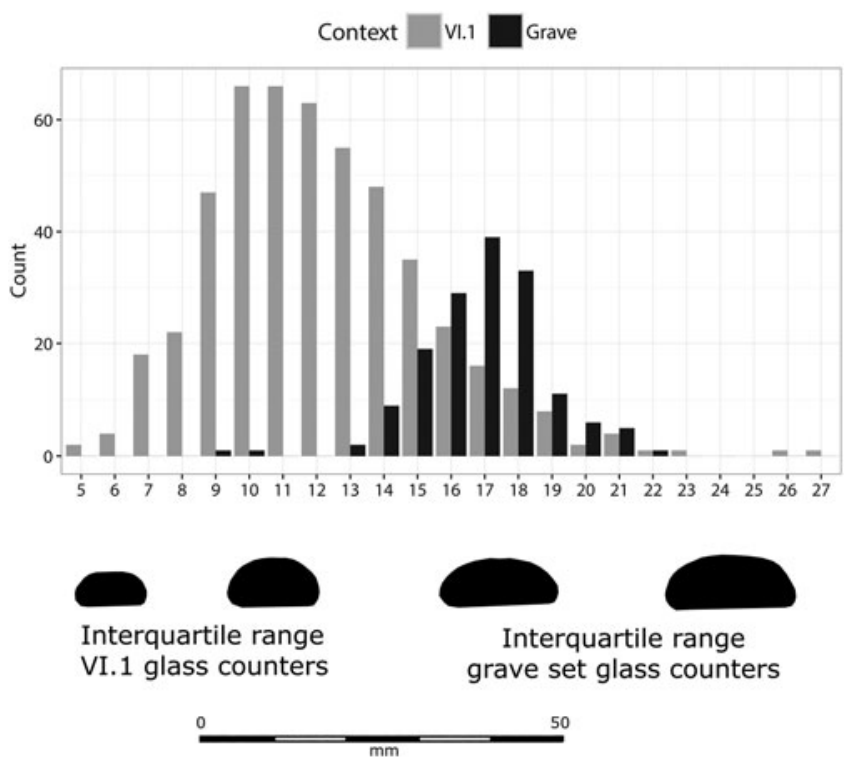

Fig. 3. A comparison of the diameters of counters from Insula VI.1 with those from first-century AD gaming sets found in graves. A bar chart of the diameters is shown above and the sections of typical counters at a scale of 1:1 below. The sections show the interquartile size range of the two data sets.

Marche) datable to the middle part of the century (Mercando, 1974: 115 nos. 1719). There are also two from graves at Stanway, just outside Colchester, datable within the AD 40-55 period, one of which is the set found laid out on a gaming board that has already been mentioned (Crummy et al., 2007: 190 no. BF64.28, 220 no. CF47.19). One set from London is of mid to late first-century date, based on the pottery of $\mathrm{AD} 40-80$ in the same grave (Barber and Bowsher, 2000: 193 no. B435.2-1-24). The final grave from Gloucester can be dated on the basis of the unguent bottles it contained and the foundation date of the site as a legionary fortress to the AD 60s and 70s (Cool, 2008: 109-10 nos. 11-43). These grave data have two outliers at 9 and $10 \mathrm{~mm}$ diameter respectively, with the main sequence between 13 and $22 \mathrm{~mm}$. The whole dataset has an interquartile range of $16-18 \mathrm{~mm}$ diameter.

The grave data and the VI.1 data are compared in Fig. 3. As this shows, the two datasets have very different size distributions. It could be argued that, as the graves have deposition dates from the mid-first century, it is possible that smaller counters may have been used in the Augusto-Tiberian period and earlier, and the VI.1 counters are reflecting this. This seems unlikely when a comparison is made with the gaming set found in the Comacchio ship (Berti, 1990: 269 no. 251). This ship must have been lost in the final years of the first century BC, as part of its cargo consisted of lead ingots stamped with the name of Marcus Agrippa, who died in 12 BC. The set consisted of 24 stone and two bone plano-convex counters with diameters of $15 \mathrm{~mm}$, which is closely comparable to the mid first-century glass sets, and would be in the upper quartile of the VI.1 range. 
The very different size distributions between the VI.1 assemblage and the grave set data would alone be sufficient to cast doubt on the identification of the bulk of the VI.1 counters as playing-pieces, but even more doubt arises when the data are compared with what is known about Roman board games, and it is to this that we now turn.

\section{ROMAN BOARD GAMES}

It has to be said at the outset that there is considerable dispute about precisely how the games recorded in the ancient sources were played. ${ }^{9}$ What is normally accepted as likely practice though is sufficient for it to be possible to establish the nature of the counters that would have been needed.

In the Roman world there were two main types of games that required counters. Ludus latrunculorum was played on a board with a squared grid and the aim was to take your opponent's pieces by placing two of your own on either side of one of theirs. Boards for this game have been found cut into stone in a variety of places across the Empire. ${ }^{10}$ The squares generally measure c. 25$30 \mathrm{~mm}$, though smaller ones do occur. This would provide an upper limit on counter size if the pieces were placed within the squares rather than on the junctions. Inspection of the grids, which can be a little irregular, suggests that, then as now, the pieces were placed within the squares. The main literary source for ludus latrunculorum, the Laus Pisonis written in the mid-first century $\mathrm{AD}$, is also explicit that black and white counters were used (Austin, 1934: 29-30 and Schädler, 1994: 64 n. 32), presumably indicating that clearly differentiated sets were required.

Ludus duodecim scriptorum (xii scripta) was played on a board set out with markings in three rows. It was similar to backgammon in that it was played with dice and the aim was to play all of your counters off the board first. It is xii scripta that the two drinkers in the wall paintings in the Caupona of Salvius are playing while arguing whether one of them has won. The sources do not state that clearly differentiated sets of counters to distinguish between the two players are needed, but the recovery of sets of black and white glass counters with dice in graves suggest this might have been preferred. If the Caupona of Salvius painting is any evidence, players could find much to argue about during play, such as what score the throw of the dice had resulted in. The potential for additional argument over whose piece had been moved if each player could not easily identify their own counters would no doubt have been high.

The bulk of the translucent counters from Insula VI.1 clearly do not pass the test of being easily distinguishable from each other. They display a continuum

9 For a consideration of the literary sources see Austin, 1934.

10 For a general consideration of boards see for example Schädler, 2007. Schädler, 1994 has an Empire-wide consideration of ludus latrunculorum boards as well as an extended consideration of the rules of the game. 


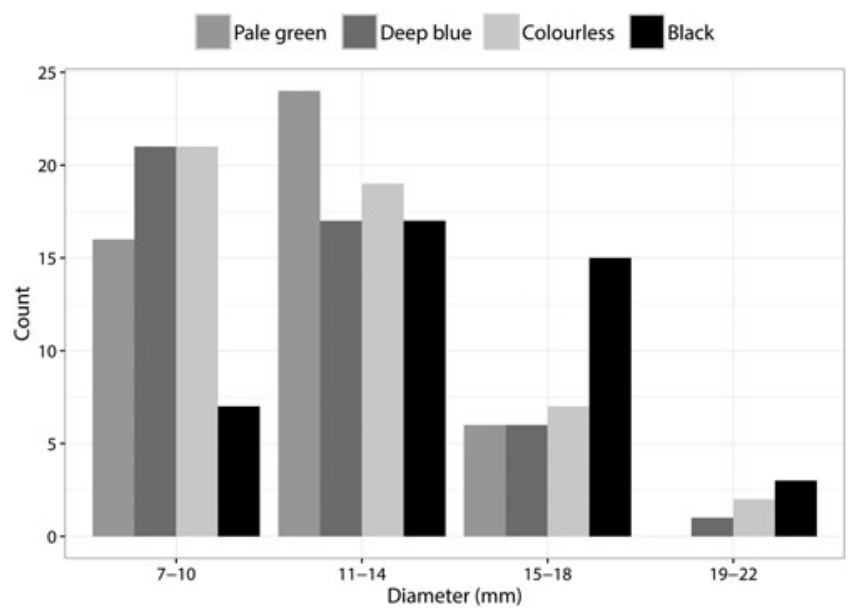

Fig. 4. Comparison of the sizes of the pale green, deep blue, colourless and black counters from Insula VI.1.

of shades that are frequently difficult even for a glass specialist to differentiate. The opaque counters by contrast can be differentiated, and it is black and opaque white glass counters that are normally found in the grave sets. Fig. 4 compares the size distribution of the black counters from Insula VI.1 with three of the translucent colours that have produced approximately the same numbers as the black counters. As can be seen, the translucent colours are poorly represented in the size category that contains the interquartile range of the counters in the grave dataset $(15-18 \mathrm{~mm})$. Black ones, by contrast, are strongly represented there, and the overall profile of their size distribution is more similar to the profile of the grave set seen in Fig. 3 than that of the translucent ones. There are suggestions here that at least some of the VI.1 black counters could well have been used for gaming. This can be tested by looking at what is coming from the four bar properties in the insula during the final stages of the city's life.

There are of course many issues that surround the interpretation of finds and their relationships to the properties. The idea that Pompeii presents a landscape frozen in time with all the objects left as they would have been in daily life has been discredited (Allison, 2004: 20-4). Doubts have also been expressed about whether renovations in a property that resulted in make-up layers with finds would have incorporated rubbish from the previous use of the property. It has been suggested that such finds are more likely to have been brought in from external rubbish dumps (Dicus, 2014). Within Insula VI.1, though, the general pattern that has been observed is that there are frequently differences in the intensity of recovery of classes of objects that can be plausibly interpreted as reflecting the activities likely to have been carried out in the property at the time. This is shown extremely well by the coins that were recovered overwhelmingly in the commercial areas such as bars where they could be expected to have been in active use (Hobbs, 2013: 100). Fragments of 

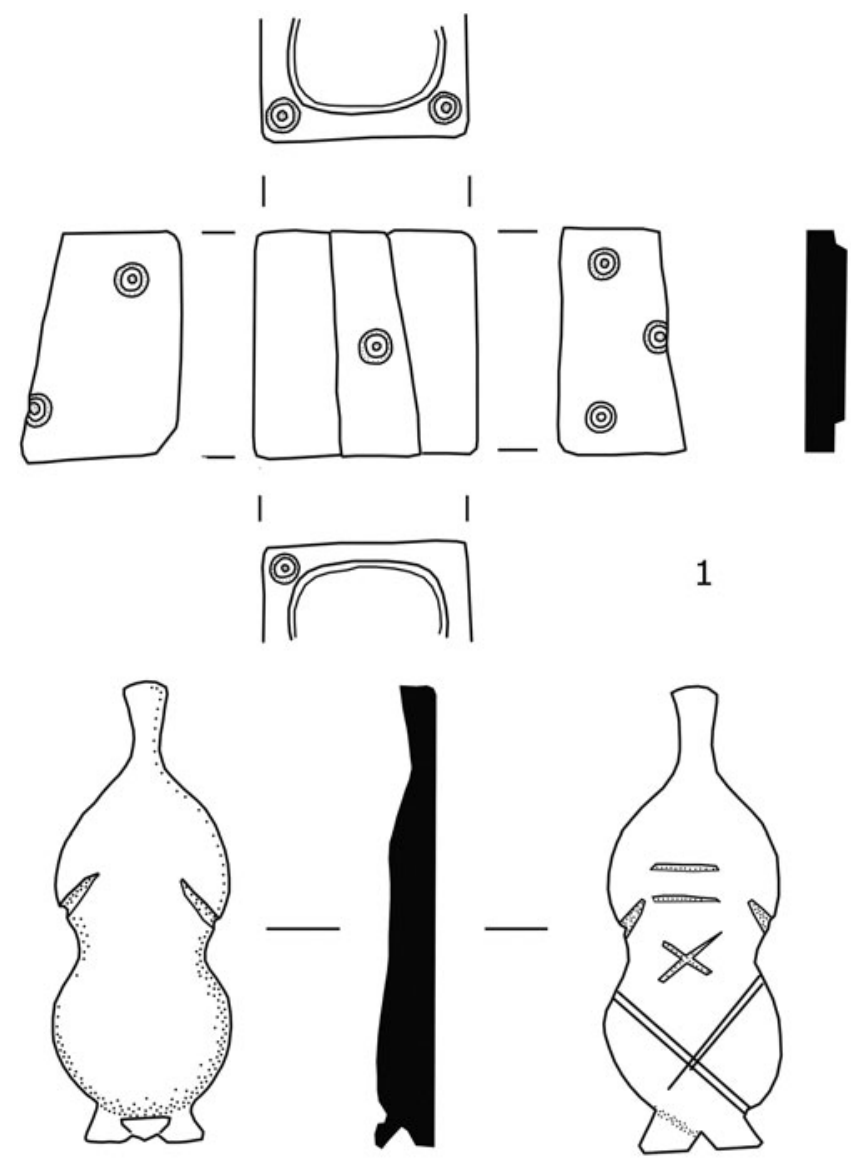

2

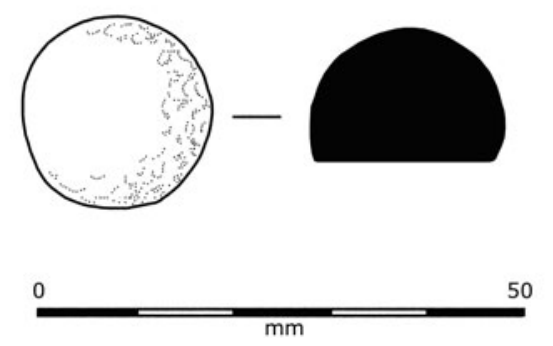

Fig. 5. Gaming equipment. 1: composite bone die from the Vestals Bar. 2: bonetrussed fowl piece from the Inn bar. 3: red porphyry counter from the bar of Phoebus. (Scale 1:1.)

perfume bottles by contrast are concentrated in areas where their contents are likely to have been used in toiletry, dining and making religious observances, that is, the houses and the open-air dining room attached to the Inn. In the light of this it seems reasonable to suggest that if items that are unambiguously 
Table 2. The distribution of the glass counters within the bar contexts and other contexts from the insula with post-earthquake and modern phasing. Small counters have a diameter of 7-14.5 mm and large counters have a diameter of $15-22.5 \mathrm{~mm}$. The percentage data presented in brackets are rounded row percentages.

\begin{tabular}{lccr}
\hline & Small counters & Large counters & Total \\
\hline Bar contexts & $18(56 \%)$ & $14(44 \%)$ & 32 \\
Other contexts & $129(85 \%)$ & $23(15 \%)$ & 152 \\
Total & 147 & 37 & 184 \\
\hline
\end{tabular}

associated with gaming are found in the bars, then gaming was probably carried out there.

Within contexts post-dating the earthquake there are three such unambiguous items in the form of two dice (Fig. 5.1) and a stone counter like the ones from the Comacchio ship (Fig. 5.3). There is also one slightly more ambiguous item in the form of a bone trussed fowl (Fig 5.2). Various functions have been suggested for the animal playing-pieces of which it is an example. Mlasowsky (1991: 25) suggests that they were tokens used when lots were drawn to choose seating positions in a symposium. Schenk (2012: 148) discusses the theory that sees them as tokens thrown by the elite to poorer people as largesse that could be exchanged for goods such as seats at the games, exotic food and money. Most people who write about them agree that one possibility is that they were used for playing a game for which there is no longer any literary evidence. The presence of examples in a grave with a wide range of gaming equipment at San Vittore di Cingoli (Mercando, 1974: fig. 41 nos. a, b, d, e) would favour the playing-piece identification.

Given these finds in the bars, the VI.1 counter data can be inspected, to see if examples of the size proposed here as being likely to have been used for gaming are found disproportionately in the bars. Table 2 shows the counters from all post-earthquake and modern contexts in the insula divided according to whether they are large (over $15 \mathrm{~mm}$ diameter) or small, and whether they come from bar properties or the rest of the insula. A size of $15 \mathrm{~mm}$ has been taken as a dividing point, as this is the point between the interquartile ranges of the VI.1 and grave datasets. If all the glass counters were appropriate for playing games, then no difference should be seen between the two types of contexts, but this is not the case. The large counters, of which of course there are far fewer, are disproportionately represented in the bar properties. This can be tested formally by a chi-squared test, which returns a p-value of 0.0006 , that is, highly significant, and the null hypothesis of no difference between the two types of contexts can be rejected.

Everything suggests that the bulk of the Insula VI.1 counters were not used in gaming unless we are prepared to posit the existence of an unattested game that, to judge from the numbers of counters recovered, must have been popular with the inhabitants. It is therefore necessary to ask what other function(s) they could have served. 


\section{COUNTING, GEMS OR INTERIOR DECORATION?}

When considering a possible function for the small translucent counters, it seems very likely that it was connected with an activity (or activities) that the inhabitants of Pompeii had need of from at least the first century BC into the mid-first century AD. This is strongly suggested by the close correspondence between the proportions of the different colours in both the counter assemblage and the cast vessel glass assemblage (see Table 3). Cast glass vessels start to appear in the VI.1 assemblage before the end of second century $\mathrm{BC}$ and a range of types were in use through the following century. The site was clearly well supplied with the Syrio-Palestinian grooved and ribbed bowls (Grose, 1989: 193-4) and later, once the Roman industries started production, fragments from those types of vessels also occur on the site in considerable numbers (Grose, 1989: 244-7).

There is a chronological progression in the colours used to make these vessels. The earlier eastern Mediterranean industries produced some deliberately decolourized green-tinged or colourless vessels, but much of the production was in naturally occurring shades of yellow/green and yellow/brown. The Roman industries favoured a brighter palette. Deep translucent blue, for example, was commonly used for the ribbed and linear cut bowls. Emerald green was

Table 3. Comparison of the colours used for glass counters and cast vessel glass expressed as percentages. The counter data is by count and the vessel data by weight.

\begin{tabular}{lcc}
\hline Colour & Counter & Cast vessel glass (g) \\
\hline Multi-coloured & 6.1 & 13.2 \\
Opaque white & 2.3 & 0.3 \\
Opaque blue & 1.4 & 0.5 \\
Opaque green & 0.9 & 0.9 \\
Opaque blue/green & 0.9 & 0.2 \\
Opaque yellow & 0.2 & - \\
Opaque red & - & 0.6 \\
Opaque pink & - & 0.8 \\
Black & 9.8 & 0.1 \\
Dark yellow/brown & 3.8 & 6.7 \\
Purple & 0.2 & 0.5 \\
Deep blue & 8.2 & 7.5 \\
Peacock & 3.2 & 1.3 \\
Emerald & 1.4 & 6.8 \\
Mid/dark green & 0.4 & - \\
Mid blue & 1.8 & 1.1 \\
Yellow/brown & 13.6 & 13.0 \\
Yellow/green & 5.0 & 2.6 \\
Pale green & 9.8 & 11.8 \\
Tinged colourless & 2.9 & 4.4 \\
Colourless & 9.3 & 7.8 \\
Blue/green & 19.1 & 19.8 \\
Total \% & 100.3 & 99.9 \\
Total number/weight & 560 & 1148.7 \\
\hline
\end{tabular}


especially favoured by the makers of a class of vessels that had angular profiles like some contemporary metal and pottery vessels (Grose, 1989: 254-6). Bi- and polychrome vessels with marbled and millefiori appearances were also more commonly made by the Roman industries than they had been before. As the Roman industries developed, blue/green glass became more dominant so that by the time of the post-earthquake contexts it was the dominant colour.

If Fig. 2 is inspected it can be seen that the chronological sequence of the counter colours is very closely aligned with the chronological development of the colours used in the cast glass vessels. It seems very likely that the counters were being made from broken fragments of cast vessels. The ribbed and grooved bowls tend to be quite thick and would have provided ideal raw material. As noted in the Introduction, the shape of the counters is the one that will naturally result when a piece of soda lime silicate glass is heated to a temperature of $c .625^{\circ} \mathrm{C}$. The strong association of the bright monochrome and multi-coloured counters with the Augusto-Neronian period and of the blue/ green counters with the post-earthquake to eruption period could be expected, as the vessels were progressively broken and entered the cullet pool. This suggests that such counters continued to be needed. The rarity of emerald green counters is interesting, but possibly to be explained by the fact that vessels made in this colour were frequently thinner-walled and so might not have provided suitably sized chunks of glass.

Various alternative functions can be suggested for these counters. They could have been accounting aids, acting as tallies. This is certainly a function sometimes suggested for bone counters (Béal, 1983: 283). They might have been used as settings in jewellery. This was one of the functions Cerato favoured when discussing the hundreds of such counters found in the relatively modest house Pompeii I.11.9, and she suggested that the house might have been the workshop of a gemmarius (Cerato, 1998: 142-5). Plain coloured settings in jewellery are known at the time, though most of those in precious metal jewellery are made of precious stones rather than glass (for example, d'Ambrosio and De Carolis, 1997: 40-2 nos. 74-86). The sheer numbers of these counters recovered in Insula VI.1 would seem to make it very unlikely they were all settings that had come loose from pieces of jewellery. To give an idea of the extent of the loss that might be expected in such circumstances, the total of only fourteen loose intaglios and three copper alloy finger rings that had lost their settings from the VI.1 excavations can be noted.

In discussing the assemblage of counters from I.11.9, Cerato went on to make the additional suggestion that perhaps they had been used as inlays in furniture. Such a decorative function seems more likely for various reasons. In the first instance it is probable that if the counters were being used in this way then multiple examples would have been used at any one time: this might account for the large numbers found. Equally, the large range of shades found would be ideal if they were being used together as decoration, allowing for a gradation in colour. As already noted, the range would have been far from ideal when playing games. 
There was certainly a considerable interest in using glass as part of interior decoration from the later first century $\mathrm{BC}$ when the material became increasingly common in everyday life. Prior to cubic glass tessera becoming a standard part of the mosaic maker's repertoire, glass in other forms such as twisted rods was being used as part of wall mosaics from the beginning of the first century AD (Boschetti, 2011: 76). A referee of this paper has suggested that the counters might have served as a substitute for the precious gems apparently depicted as being used to decorate columns in some Second Style wall paintings (Ling, 1991: 16). Coloured glass counters such as the ones under consideration here certainly formed part of the stucco-decoration of a ceiling in the Domus Transitoria built for Nero on the Palatine at Rome (Bacchelli et al., 2000: 86 fig. 3). They can also be observed as part of the decoration on the front of the nymphaeum that was incorporated into the Casa di Augusto on the Palatine in Rome. It should also be remembered that Pliny the Elder (Natural History 36.94) described the development of mosaic on vaulted ceilings as being 'now made of glass' and went on to say, 'Here too we have a recent invention.'

None of the VI.1 counters retained any mortar to suggest that they came from mosaics, but the recent reconstruction of the suspended wooden ceiling from the marble room in the House of the Telephus at Herculaneum reminds us how sophisticated the joinery was at that time, and how bright and colourful the rooms would have been. In that ceiling considerable use was made of boards with applied elements, and an organic glue was identified (Camardo and Notomista, 2015: 53 n. 51). If the counters had been glued to anything, traces of the glue would be unlikely to survive as currently they are normally found covered by thick flaking iridescence that represents the decay of the surface. Using the counters as decorative elements either inlaid or glued to wooden furniture, ceiling elements or other fittings is a distinct possibility. Alhough Mols (1999: 109-10) found no evidence for the use of glass inlays in the Herculaneum wooden furniture, there was clearly an interest in exploiting colour contrasts in furniture, and the use of a variety of materials is attested more generally (De Carolis, 2007: 77-8). Within the VI.1 assemblage there were numerous small shaped bone inlays of the sort that have been found elsewhere decorating items of wooden furniture. ${ }^{11}$ These attest to furniture items covered in complex and possibly figural marquetry. Some small, flat, shaped glass pieces from the site also hint at the use of glass for furniture inlay as they are much smaller than the elements recovered that clearly came from opus sectile floors. So, while none of the Herculaneum wooden furniture retains any elaborate inlaid and/or coloured decoration, it would be unwise to rule out

11 For examples of ones still in situ see a wooden casket found in a grave belonging to the second half of the second century at Mangalia (Romania), which had a geometric decoration around the edges consisting of alternating triangles of dark wood and light bone (De Nuccio et al., 1990: 66 figs. 43, 47). A similar use of the contrast between dark wood elements and pale bone ones can be seen on the inlay that covers the style of an oak cupboard door found in Hayton (England) (Hartley et al., 2006: 176-7 no. 138). 
its existence in the Vesuvian cities and there is a possibility that glass counters played a role in this.

The translucent counters, derived as they probably were from broken fragments of cast bowls, would not have needed a high level of craft skill to make. The temperature required to soften the glass was not very high in comparison with many manufacturing activities involving glass at the time. Given the range of sizes and sometimes irregular shapes shown by the VI.1 assemblage, there appears to have been no need for strict quality control as far as those areas were concerned. This is in marked contrast with the glass counters definitely used in gaming. There a strict control over size was exercised, and it is rare to get irregular shapes. The glasses they were made from were also specialist. As can be seen from Table 3, black vessel glass was vanishingly rare in the VI.1 assemblage, and this is the case in general. The same is true of opaque white glass. Chemical analysis of a range of counters from elsewhere in Pompeii has confirmed the specialist nature of the white and black glass in the counters and the likelihood that the translucent ones were reused vessel fragments (Arletti et al., 2006: 178-9, 182).

Specialist glasses would need to have been made or acquired as blocks of raw glass. All of this points to the fact that not only were the counters intended for different functions, but they were probably also made by different types of craftsmen. This might have been either in different workshops, or possibly in the same ones but by craftsmen at different stages of their career. The production of the translucent counters might well have been a good training exercise for apprentices learning the working qualities of glass. It was a material that was becoming increasingly popular and widely used as the first century AD progressed. The numbers of people working with glass would have been growing to accommodate this, and it seems very likely that different specialisms would have developed. Where the workshops making the glass counters found within VI.1 were located is an interesting question. The Roman glass industries can be divided into two types: primary glass-forming industries that made glass from raw ingredients, and secondary glass-working industries that fashioned this glass and cullet into vessels and objects. Installations could carry out both, but evidence generally points to them being separate. The counters would have been the products of secondary glass-working industries, very likely located in the town or its environs. The correspondence between the colours of the counters and the colours of the vessel fragments seen in Table 3 strongly suggests an exploitation of local cullet.

It is hoped that this paper has shown that it can be unwise to base assumptions of function on the names we casually apply to objects with all their modern overtones. Standing back and looking at what the data themselves may be telling us can often suggest that something quite different was going on. Disentangling what functions the Insula VI.1 counters might have served suggests two things. One is that we may have been underestimating the role glass was playing in interior decoration at Pompeii in the century before the city was destroyed. The second, relating to the rise of specialist black and white 
counters, is that the demand for counters specifically intended for gaming was increasing.

Glass gaming counters were not obviously replacing those made of other materials. The rise of bone gaming counters would appear to be a contemporary phenomenon, as can be seen from Béal's useful summary of the incidence of the various common types from the first century BC onwards (Béal, 1983: 317). This summary shows that the bone counters are overwhelmingly of a first- to third-century AD date, with the main focus on the second to third centuries.

The material culture of the cities and other sites destroyed by Vesuvius in AD 79 is often taken as typical of the kinds of objects a Roman community needed for its everyday life. An important conclusion that can be drawn from the large finds assemblage from the VI.1 excavations is that many of the eruption level types were very new when Pompeii was destroyed. Their introduction reflects a market that was demanding ever more specialized types to service changes in the ways people were conducting their daily lives. ${ }^{12}$ The demand for specialized glass gaming counters, and in far larger numbers than had previously been desired, is an aspect of these changes. The logical conclusion to draw is that more people were playing the games that required the counters. Does this mean that an increasing number of people had more free time to indulge in such pastimes? An intriguing possibility; and one that underlines the value of studying small finds with due care.

Address for correspondence:

Dr H.E.M. Cool

Barbican Research Associates, 16 Lady Bay Road, West Bridgford, Nottingham, NG2 5BJ, United Kingdom.

hilary@coolarchaeology.com

\section{Acknowledgements}

It is a great pleasure to acknowledge the courtesy of the Soprintendenza Speciale Beni Archeologici Pompei Ercolano Stabia and its predecessors for allowing me to work with the material from Insula VI.1, and to thank the many people in the Soprintendenza who, over the years, have given me access to the stores and the library. The AAPP was directed by Rick Jones and Damian Robinson, and it was at their invitation that I started work on the VI.1 material. My debt to my fellow-specialists on the VI.1 postexcavation project is very great. For this paper thanks are especially owed to Michael Anderson, who has supplied the phasing for the areas of the Casa del Chirurgo, the Inn and the Triclinium. I am also extremely grateful to the Society of Antiquaries of London, the British Academy, Nottingham Trent University (RAE funding) and the Roman Society for financial support that enabled the specialist teams to work in the field from 2007 to 2011, during which time part of the data for this paper was catalogued. My thanks also to Mike Baxter for producing Fig. 2, and to the two anonymous readers for their comments and suggestions. I would also like to thank

12 This is more fully discussed in Cool, forthcoming. 
everyone at the British School at Rome for their hospitality at various times when some of the background research for this paper was conducted in the library.

\section{REFERENCES}

Allison, P.M. (2004) Pompeian Households: An Analysis of Material Culture (Cotsen Institute of Archaeology Monograph 42). Los Angeles, University of California. See also accompanying database at: www.stoa.org/pompeianhouseholds.

Arletti, R., Ciarallo, A., Quartieri, S., Sabatino, G. and Vezzalini, G. (2006) Archaeometric analyses of game counters from Pompeii. In M. Maggetti and B. Messiga (eds), Geomaterials in Cultural Heritage (Geological Society Special Publication 257): 175-86. London, Geological Society.

Austin, R.G. (1934) Roman board games. I. Greece and Rome 4: 24-34.

Bacchelli, B., Pasqualucci, R. and Mastrodanato, V. (2000) Glass in interior decoration and furniture in the Roman Imperial period. In Annales du 14e congres de l'Association Internationale pour l'Histoire du Verre Italia Venezia-Milano 1998: 86-8. Lochem, L'Association Internationale pour l'Histoire du Verre.

Barber, B. and Bowsher, D. (2000) The Eastern Cemetery of Roman London: Excavations 19831990 (Museum of London Archaeology Service Monograph 4). London, Museum of London Archaeology Service.

Béal, J-C. (1983) Catalogue des objets de tabletterie du musée de la civilisation gallo-romaine de Lyon (Centre d'Etudes Romaines et Gallo-Romaine de l'Université Jean Moulin Lyon III. Nouvelle série 1). Lyon, De Boccard.

Beard, M. (2008) Pompeii: The Life of a Roman Town. London, Profile Books.

Berry, J. (2007) The Complete Pompeii. London, Thames and Hudson.

Berti, F. (1990) (ed.) Fortuna maris: la nave romana di Comacchio. Bologna, Nuova Alfa Editorale.

Boschetti, C. (2011) Vitreous materials in early mosaics in Italy: faience, Egyptian blue, and glass. Journal of Glass Studies 53: 29-91.

Camardo, D. and Notomista, M. (2015) The roof and suspended ceiling of the marble room in the House of the Telephus at Herculaneum. Journal of Roman Archaeology 28: 40-70.

Cerato, I. (1998) La casa I, 11, 9, 15 di Pompei. Università degli studi di Pisa. Facoltà di lettere e filosofia, corso di Laurea in Lettere. Tesi di Laurea.

Cool, H. (2008) The small finds. In A. Simmonds, N. Marquez-Grant and L. Loe (eds), Life and Death in a Roman City: Excavation of a Roman Cemetery with a Mass Grave at 120-122 London Road, Gloucester (Oxford Archaeology Monograph 6): 104-15. Oxford, Oxford Archaeology.

Cool, H.E.M. (forthcoming) The Small Finds and Vessel Glass from Insula VI.1 Pompeii: Excavations 1995-2006. Oxford, Archaeopress.

Cool, H.E.M. and Baxter, M.J. (1999) Peeling the onion: an approach to comparing vessel glass assemblages. Journal of Roman Archaeology 12: 72-100.

Crummy, N. (1984) The Roman Small Finds from Excavations in Colchester 1971-9 (Colchester Archaeological Report 2). Colchester, Colchester Archaeological Trust.

Crummy, P., Benfield, S., Crummy, N., Rigby, V and Shimmin, D. (2007) Stanway: An Elite Burial Site at Camulodunum (Britannia Monograph 24). London, Society for the Promotion of Roman Studies.

d'Ambrosio, A. and De Carolis, E. (1997) (eds) I monili dall'area Vesuviana (Ministero per i Beni Culturali ed Ambientali. Soprintendenza archeologica di Pompei. Cataloghi 6). Rome, 'L'Erma' di Bretschneider.

d'Ambrosio, A., Guzzo, P.G and Mastroroberto, M. (2003) (eds) Storie da un'eruzione, Pompei Ercolano Oplontis. Naples, Electa.

De Carolis, E. (2007) Il mobile a Pompei ed Ercolano. Rome, 'L'Erma' di Bretschneider. 
De Nuccio, M., Donato, G. and Donato, E. (1990) La dama di Callatis. In P. Virgili and C. Viola (eds), Bellezza e seduzione nella Roma Imperiale: 63-7. Rome, De Luca Edizioni d'Arte.

Dicus, K. (2014) Resurrecting refuse at Pompeii: the use-value of urban refuse and its implications for interpreting archaeological assemblages. In H. Platts, J. Pearce, C. Barron, J. Lundock and J. Yoo (eds), TRAC 2013: Proceedings of the Twenty-Third Theoretical Archaeology Conference, King's College, London 2013: 65-78. Oxford, Oxbow.

Fiorelli, I. (1860) Pompeinarum antiquitatum historia I. Naples. [No publisher stated.]

Foy, D. (2010) Les verres antiques d'Arles. La collection du musée départemental Arles antique. Paris, Editions Errance.

Greene, K. (2008) Learning to consume: consumption and consumerism in the Roman Empire. Journal of Roman Archaeology 21: 64-82.

Grose, D.F. (1989) Toledo Museum of Art: Early Ancient Glass. New York/Toledo, Hudson Hills Press.

Hartley, E., Hawkes, J., Henig, M. and Mee, F. (2006) Constantine the Great: York's Roman Emperor. York, York Museums and Galleries Trust in association with Lund Humphries.

Hobbs, R. (2013) Currency and Exchange in Ancient Pompeii: Coins from the AAPP Excavations at Regio VI, Insula 1 (Bulletin of the Institute of Classical Studies Supplement 116). London, University of London.

Jones, R. and Robinson, D. (2004) The making of an élite house: the House of the Vestals at Pompeii. Journal of Roman Archaeology 17: 107-30.

Jones, R. and Robinson, D. (2005a) The economic development of the Commercial Triangle (VI.1.14-18, 20-1). In P.G. Guzzo and M. Guidobaldi, M. (eds), Nuove ricerche archeologiche a Pompei ed Ercolano: 270-7 (Studi della Soprintendenza Archeologica di Pompei 10). Naples, Electa.

Jones, R. and Robinson, D. (2005b) Water, wealth, and social status at Pompeii: the House of the Vestals in the first century. American Journal of Archaeology 109: 695-710.

Jones, R. and Robinson, D. (2007) Intensification, heterogeneity and power in the development of Insula VI.1. In J.D. Dobbins and P.W. Foss (eds), The World of Pompeii: 389-406. London/ New York, Routledge.

Keenan-Jones, D. (2015) Somma-Vesuvian ground movements and the water supply of Pompeii and the Bay of Naples. American Journal of Archaeology 119: 191-215.

Ling, R. (1991) Roman Painting. Cambridge, Cambridge University Press.

Lockyear, K. (2013) Applying bootstrapped Correspondence Analysis to archaeological data. Journal of Archaeological Science 40: 4744-53.

Mercando, L. (1974) Marche. Rinvenimenti di tombe di età romana. Notizie degli Scavi di Antichità 99: 88-141.

Mlasowsky, A. (1991) Die antiken Tesseren im Kestner-Museum Hannover (Sammlungskatalog 10). Hannover, Kestner-Museum.

Mols, S.T.A.M. (1999) Wooden Furniture in Herculaneum: Form, Technique and Function. Amsterdam, J.C. Gieben.

Murphy, C.A. (2015) Romans, Rubbish and Refuse: The Archaeobotonical Assemblage of Regione VI, Insula I, Pompeii (Archaeopress Roman Archaeology 8). Oxford, Archaeopress.

Parslow, C.C. (1995) Rediscovering Antiquity: Karl Weber and the Excavation of Herculaneum, Pompeii and Stabiae. Cambridge, Cambridge University Press.

Pitts, M. (2014) Reconsidering Britain's first urban communities. Journal Roman Archaeology 27: 133-73.

Pitts, M. and Perring, D. (2006) The making of Britain's first urban landscapes: the case of Late Iron Age and Roman Essex. Britannia 37: 189-212.

Roberts, P. (2013) Life and Death in Pompeii and Herculaneum. London, British Museum Press. 
Rütti, B. (1988) Beiträge zum römischen Oberwinterthur. Vitudurum 4: Die Gläser (Berichte der Züricher Denkmalpflege 5). Zurich, Orell Füssli Verlag.

Schädler, U. (1994) Latrunculi - ein verlorenes strategisches Brettspiel der Römer. Homo Ludens. Der spielende Mensch 4: 47-67.

Schädler, U. (2007) The doctor's game - new light on the history of ancient board games. In P. Crummy, S. Benfield, N. Crummy, V. Rigby and D. Shimmin (eds), Stanway: An Elite Burial Site at Camulodunum (Britannia Monograph 24): 359-75. London, Society for the Promotion of Roman Studies.

Schenk, A. (2012) Deux objets insolites à représentation zoomorphe. Bulletin de l'Association Pro Aventico 53: 147-8.

Schojer, T. (1988) La necropoli di Contrada Corti Vecchie. In A. Alessio, C. D’Angela and A. D'Amicis (eds), Il museo di Taranto: cento anni di archeologia (Catalogo della mostra per il centenario dell Museo Archeologico Nazional di Taranto): 469-521. Taranto, Mandese Editore.

Stern, E.M. and Schlick-Nolte, B. (1994) Early Glass of the Ancient World 1600 BC-AD 50. Ostfildern: Verlag Gerd Hatje.

Varone, A. (2003) Il gioco. In G. Stefani (ed.), Menander: la casa del Menandro di Pompei: 192-3. Milan, Electa.

Ward-Perkins, J. and Claridge, A. (1979) Pompeii AD 79. Bristol, Imperial Tobacco Limited. 